\title{
INNOVATIONS IN PUBLIC UTILITY ACCOUNTING REGULATION
}

\author{
E. W. MOREHOUSE $\uparrow$
}

A NEw DEAL in public utility accounting control has been in the making during the past five years. During 1936, the movement reached its peak with six new or revised systems of accounts ${ }^{1}$ prescribed, recommended, enacted and even tested in the courts. Four of them vere ordered by federal regulatory agencies; but the state commissions initiated and sponsored many of the novel principles in two of the federal systems. Their point of view is represented in the systems of accounts for electric and gas utilities recommended by the National Association of Railroad and Utilities Commissioners in November, 1936, a significant recommendation despite the fact that it was nominally made after the Federal Power Commission had prescribed a substantially identical system of accounts for electric utilities under its jurisdiction. A system of accounts for telephone utilities was ordered by the Federal Communications Commission late in 1935 but restraining orders or temporary injunctions made it inoperative until December 7, 1936, when the Supreme Court upheld the accounting system as constitutional. ${ }^{2}$ And the Securities and Exchange Commission has prescribed two new systems of accounts, one for mutual service companies and the other for holding companies.

It has long been recognized by forward-looking commissions that chapter one of effective regulation begins with accurate, revealing, and uniform accounts and accounting statements. Unless a commission has readily available for quick use the information needed to perform its duties, it is hobbled at the start of any investigation. One of the chief criticisms of commission regulation of public utilities is a characteristic

$\dagger$ Chief, Rates and Research Division, Public Service Commission of Wisconsin. The writer gratefully acknowledges the helpful advice and assistance of Judge Alvin $C$ Reis, A. R. Colbert and B. J. Sickler, who have read the manuscript, and of R. C. Wenzel and W. H. Evans, who aided in its preparation.

1. Federal Comarunicatrons Cousurission, Untroars Systeas of Accounts foz Telephone Compantes; Federal Power Courzission, Uziroras Systear of Accounts for Public Utimities and Licensees; National Assoctation of Ratrond arto UtTutIEs Commitssioners, Uniform 'Systers of Accounts for Electric Uturties AND

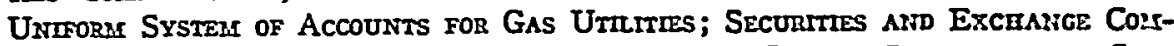
amssion, Untropis Systems of Accounts for Mfutuar Service Cosspasies and Sudsmiary Service Couspantes and Untrorar System of Accounts for Pudut Utuity Holonsg Courpastes.

The Interstate Commerce Commission has under consideration a uniform system of accounts for motor carriers, which is not considered in this article.

2. American Tel. and Tel. Co. v. United States, 57 Sup. Ct. 170 (1936). 
delay in completing investigations and reaching conclusions. ${ }^{3}$ No small part of this delay has been caused by time-consuming and expensive audits (and appraisals) to uncover facts, many of which should be shown on the face of the accounts. To the general public, accounts and accounting seem prosaic matters; they do not make the headlines. Yet they are indispensable to regulation. ${ }^{4}$

The current movement for utility accounting reform arose from a growing conviction that prior systems of accounts were unable to furnish essential information quickly. Most of the prior systems antedated $1924 .^{5}$ Almost as soon as they were initiated, the utility industries entered upon an era of consolidation, ${ }^{6}$ securities speculation, transactions between affiliated interests, investment banker domination, and system building through growth of transmission lines and interconnections. The older systems of accounts were not designed with such transactions or developments in view. The abuses of the period, comprehensively disclosed by the Federal Trade Commission investigation, ${ }^{7}$ were such as could not be detected readily from the accounts or statistical reports. The system of administrative regulation became greatly hampered. When the depression came, the public was inclined to condemn the entire institution as a failure because it seemed slow and cumbersome.

Depressions are traditionally a time for overhauling governmental and econumic institutions. So it was with public utility regulation. What many believe, or hope, is that a renascence of utility regulation has set in, stimulated and aided by the expansion of federal control over utilities; one of the first undertakings in this period of renewed energy was the reform of obsolete systems of accounts.

The official lineage of the more novel principles in the new accounting systems dates back at least to $1931 .^{8}$ In that jear the Public Service

3. See dissenting opinion of Mr. Justice Brandeis, St. Joseph Stock Yards Co, v. United States, 298 U. S. 38, 88 (1936).

4. Among their first activities both the Securities and Exchange Commission and the Interstate Commerce Commission, Bureau of Motor Carriers, started devising uniform accounting regulations under the regulatory authority granted to them. Thus the annual report of the American Telephone \& Telegraph Co. for 1936 represents a new accounting procedure for the Bell System undertaken to meet the requirements of the Securities and Exchange Commission. N. Y. Times, Mar. 1, 1937, p. 27, col. 2.

5. The last accounting system for electric utilities recommended by the National Association of Railroad and Citilities Commissioners was adopted in 1922; the Federal Power Commission classification of accounts for licensees was adopted in 1922. No revision of the sistem of accounts for telephone companies was made between 1913 and 1933.

6. Bonbright and Means, The Holding Company (1932).

7. Federal Trade Commission, Utility Corporations, Sen. Doc. No. 92(72-A), 70th Cong., 1st Sess. (1928).

8. Public Service Commission of Wisconsin, Partial Revision of 1923 Uniform Classification of Accounts for Class A Electric Utilities, 2-U-66, Nov. 24, 1931. 
Commission of Wisconsin ordered a partial revision of its system of accounts for electric utilities. In the revised system, electric utilities were required to record all property built or acquired in the future at "original cost"- that is, cost at the time the property was first devoted to public service. A separate account, "Fixed Capital Purchase Adjustment," was provided to record the difference between original cost and what the acquired property cost the accounting utility. In addition, stock discount and selling expense were segregated among the assets on the balance sheet, instead of being "buried" in "Organization Expense" among the fixed capital accounts. New accounts were provided on the balance sheet and in operating expenses to record transactions between affiliated interests. These three innovations were the most striking features of Wisconsin's partial revision of its utility accounting system in 1932.

The New York Public Service Commission went further in the same direction. In 1934 and 1935, completely revised systems of accounts for electric, gas, omnibus, telephone, and water utilities were prescribed. ${ }^{\circ}$ The New York Commission likewise required plant to be recorded at original cost but it also provided that the excess of purchase price above original cost should be written off to net income or surplus. Segregation of stock discount and selling expense, and of transactions between affiliated interests, was also required. In addition, New York ordered transmission plant to be classified separately from distribution plant, prescribed straight-line depreciation accounting, and required income taxes to be recorded as a deduction from income after interest.

Meanwhile, the National Association of Railroad and Utilities Commissioners had instructed its Committee on Utility Statistics and Accounts of Public Utility Companies to prepare revised systems of accounts for electric and gas utilities. ${ }^{10}$ At the 1935 convention a draft of an accounting system for electric utilities was submitted ${ }^{11}$ but in view of the then recent enactment of the Federal Power Act ${ }^{12}$ and the Public Utility Holding Company Act, ${ }^{13}$ the Association instructed its accounting committee to consider the suggestions of the Federal Power and the Securities and Exchange Commissions, as well as the suggestions of the utilities,

9. New York Public Service Commission: Electric, ordered Nov. 23, 1933, effective Jan. 1, 1934; Gas, ordered Nov. 23, 1933, effective Jan. 1, 1934; Omnibus, ordered Nov. 23, 1933, effective Jan. 1, 1934; Water, ordered Nov. 23, 1933, effective Jan. 1, 1934; Telephone, ordered June 26, 1934, effective Jan. 1, 1935.

10. National Association of Railioad and Utmitres Cozurissioners, Proceedings, 45th Anzual Convention (1933) 459.

11. Id. 47tr Annual Convention (1935) 110.

12. Federal Power Act, 49 Stat. 838, 16 U.S. C. A. $\$ \$ 791 a, 796-800,803$, 807, 810, 811, 816-818, 824-824h, 825-825r (Supp. 1935).

13. Public Utility Holding Conipany Act of 1935, 49 Stat. 838, 15 U. S. C. A. $\S \S 79-79 z-6$ (Supp. 1935). 
for a revision of the 1935 draft. Out of numerous meetings came a revised system of accounts for electric utilities, prescribed by the Federal Power Commission in June, 1936, effective January 1, 1937, and in substantially identical form approved by the Executive Committee of the Association in June and recommended by the Association at its annual convention in November, 1936. At the same time the Association recommended an accounting classification for gas utilities which follows the essential major principles of the electric system.

The regulatory spotlight then turned to the United States Supreme Court. It had under consideration the uniform system of accounts for telephone utilities, prescribed by the Federal Communications Commission, and its decision in effect upheld the major new principles not only of the telephone classification but also of the electric classifications of the Federal Power and state commissions, as well as the classification for gas companies, for all these systems of accounts are based in large measure upon the so-called "original cost" principle, which was the chief point of attack in the American Telephone and Telegraph Company case. $^{14}$

The whole movement for public utility accounting reform is recapitulated in the history of the system of accounts for telephone companies. The Interstate Commerce Commission prescribed the first system of uniform accounts for telephone companies, effective January 1, 1913. The first revision of this classification was made effective just two decades later, January 1, 1933, by the same agency. Most of the state commissions joined in strenuous protests against this revised system. Among the chief allegations was that the revision combined certain accounts so as to obscure information needed by the states in regulating telephone rates. The states also argued for the "original cost" basis of recording telephone plant.

This protest from the state commissions prompted the Interstate Commerce Commission to re-open the case for hearing although it did not stay the effectiveness of the classification. Over a hundred specific criticisms were presented by the state commissions and all except a few were disapproved by the Interstate Commerce Commission in a report of recommendations issued July $9,1934 .{ }^{15}$ The report was limited to recommendations without order, because before its issuance the Congress passed the Federal Communications Act, whereby the Federal Communications Commission inherited the Interstate Commerce Commission's jurisdiction over telephone accounting. ${ }^{16}$

14. 57 Sup. Ct. 170 (1936).

15. 203 I. C. C. 13 (1934).

16. Federal Communications ACt, 48 Stat. 1064, 47 U. S. C. $\$ 151$ (1934). 
The Communications Commission gave more sympathetic consideration to the pleas of the state commissions. After hearings and conferences, with both state commissions and company officials, the system of accounts involved in the American Telephone and Telegraph Company case was prescribed, ${ }^{17}$ effective January 1,1936 . In this system which had been recommended to the state commissions by the National Association of Railroad and Utilities Commissioners at its 1935 convention, ${ }^{13}$ most of the ideas contended for by the state commissions were adopted.

2.

It is possible here to call attention only to a few of the major changes in practice required by the new systems of accounts, like (1) statement of plant accounts on the basis of original cost, (2) separate classification of transmission and distribution plant and expenses, (3) segregation of capital stock discount and selling expense, (4) segregation of transactions between affiliated interests, (5) depreciation accounting, (6) uniformity of state and federal classifications.

(1) Original Cost Principle. The accounts provided for recording the ledger cost of utility plant for balance sheet purposes in the new and old systems of accounts for electric utilities when compared present this picture $:^{19}$

New
Account No. CArTION
100 Utility Plant
$100-1$ Utility Plant in Service
$100-2$ Utility Plant Leased to Others
$100-3$ Construction Work in Progress
$100-4$ Utility Plant Held for Future
Use -
$100-5$ Utility Plant Acquisition Ad-
$100-6$ Justments
$\begin{gathered}\text { Utility Plant in Process of Re- } \\ \text { classification }\end{gathered}$

Account No. Old Captron

101 Fixed Capital

107 Utility Plant Adjustments

Account 100 is a summary of accounts $100-1$ to $100-6$, inclusive. A utility may elect or a commission may require, in the annual

17. Federal Communications Commission, Telephone Division, Order No. 7-C, June 19, 1935.

18. Nationat Association of Ramiond and Utmitres Cozsusissioners, ProceedInGS, 47TH ANNUAL Conventron, (1935), 480.

19. The provisions described are talken from the system of accounts recommanded by the National Association of Railroad and Utilities Commissioners. Substantially similar provisions will be found in the Federal Power Commission's classification. These provisions are a later formulation than those in the Federal Communications Commission classification. 
report of the utility or otherwise, that the amounts recorded in the separate accounts be shown. Account 100-1 includes the original cost of plant in service, original cost being defined as the cost at the time the property was first devoted to public service, whether by the present owner or a preceding owner. Accounts $100-2$ and $100-3$ are self-explanatory. In Account $100-4$ is to be included the original cost, defined as above, of property owned and held for use in utility service in the future "under a definite plan for such use."

In view of the controversy aroused by account 100-5, Utility Plant Acquisition Adjustments, its text is quoted in full:

"A. This account shall include the difference between (a) the cost to the accounting utility of utility plant acquired as an operating unit or system by purchase, merger, consolidation, liquidation or otherwise, and (b) the original cost, estimated if not known, of such property, less the amount or amounts which may be credited. to the depreciation and amortization reserves of the accounting utility at the time of acquisition with respect to such property. The account shall be so subdivided, when practicable, as to show the amounts applicable to utility plant in service, utility plant leased to others, and utility plant held for future use. (See utility plant instructions 2,3 , and 4 ).

" $\mathrm{B}$. Whenever practicable, this account shall be subdivided according to the cliaracter of the amounts included herein for each property acquisition.

"C. The amounts recorded in this account with respect to each property acquisition. shall be depreciated, amortized, or otherwise disposed of, as the Commission may approre or direct." ${ }^{20}$

This account is to be used only when an operating unit or system is acquired: that is, it would be unnecessary to find the original cost of a small section of pole line, carred out of another utility's systen.

Account $100-6$ is intended as a temporary place for recording the balances in the old plant accounts until reclassification according to the new system has been accomplished. Account 107. Utility Plant Adjustments, was provided to segregate "write-up)s" of book cost, at the effective date of the system of accounts, above cost to the accounting utility. The account carries a note cautioning against construing it as approving or authorizing the recording of appreciation of utility plant.

The new plant accounts on the balance sheet are merely subdivisions of the one old account for "Fixed Capital." Further classification of "Plant in Service" is provided in detailed plant accotmts, similar to those

20. Cf. Account 100-4 Telephone Plant Acquisition Adjustment in the Federal Communications Commission classification for telephone companies, as ordered on June 19, 1935 (supra, note 17) and as modified on Jan. 7, 1937 (infra, note 35). 
in the old systems. Except for the separation of transmission from distribution plant and the elimination of capital stock discount and expense from intangible property, discussed later, there appears to be little controversy over these primary plant accounts.

The use of the new accounts may be illustrated as follows: Assume Company A buys all the property of Company B for $\$ 1,000,000$. Assume further that the original cost of this property is found to be $\$ 900,000$ and the accrued depreciation at time of purchase is estimated at $\$ 100,000$, or a net original cost of $\$ 800,000$. Company A would record in Account $100-1$ the original cost of $\$ 900,000$, and in its depreciation reserve, $\$ 100,000$. The difference between the amount paid for the property $(\$ 1,000,000)$ and the net property recorded $(\$ 800,000)$, which is $\$ 200,000$, would be recorded in Account 100-5, Utility Plant Acquisition Adjustments. Thus both the cost of the property to the accounting utility and the original cost of the property can be recorded.

Certain problems may arise in connection with the disposition of amounts recorded in the Acquisition Adjustment account. A utility may seek to retain these amounts in this account until the property to which they refer is retired from service. If the excess above original cost paid for such property were a fair amount, arrived at in arms-length dealings, this disposition probably would be approved by a commission. If the origin of the excess were otherwise, some other disposition might be required, according to the circumstances of each case.

There are three accounts through which acquisition adjustments may be depreciated, amortized, or otherwise written off. A special account 505, Amortization of Utility Plant Acquisition Adjustments, is provided in the operating expense group, coordinate with account 503, Depreciation. If written off through this account, the ratepayers bear the burden. The amounts may be extinguished through account 537, Miscellaneous Amortization, which is grouped with Income Deductions, after interest. In that event, or if written off against earned surplus of prior years, the burden falls on stockholders. ${ }^{21}$

(2) Separate Classification of Transmission and Distribution Plant and Expenses. The older systems of accounts made no distinction bebetween transmission and distribution property in the detailed plant accounts. The new systems make such a separation and carry the same

21. The New York Public Service Commission, in revising its system of ascounts, effective Jan. 1, 1934, likewise required the "operating property" accounts to be stated on the basis of original cost. If the utility paid more for purchased property than its original cost less accrued depreciation at time of acquisition, the excess was to be carried in Account 143, Suspense to be Amortized. Any amortization of excess bools cost over original cost was included in Account 456, Aliscellaneous Amortization, which is one of the income deduction accounts after interest on debt. In this position in the income account, writing off the excess is a stockholders' burden. 
separation into the operating expense accounts. To do this requires a definition of transmission for purposes of accounting. Briefly stated, the definition of transmission plant includes (a) conversion stations at a primary source of supply, such as generating plants; (b) land, structures, lines and equipment between "a generating or receiving point and the entrance to a distribution center or wholesale point"; and (c) lines and equipment whose primary purpose is to tie together sources of power supply.

The Federal Power Commission and the National Association have identical instructions on this point. The New York system of accounts uses different terminology, but the differences in substance are largely of technical interest only. The National Association's classification for gas utilities has a similar separation between transmission and distribution, adapted to the operations and terminology of that industry.

(3) Segregation of Capital Stock Discount and Selling Expense. All the new systems of accounts here considered, with the partial exception of the New York plan, ${ }^{22}$ provide separate balance sheet accounts for discount on capital stock, and commissions and expenses incurred in the issuance and sale of stock. Heretofore such costs have been treated as part of organization expense which has been, and still is, included among the intangible property accounts. The present view is that these costs are of a financial character, similar to discount and expense incurred in the issuance and sale of debt obligations, even though capital stock has no maturity date. Treating them as costs of financing, it is felt that such costs should be separately shown ${ }^{23}$ and not used to increase the property and plant account.

All the new classifications permit the amortization or writing off of these financing costs to earned surplus, and, at least to a limited extent, the accounting systems prescribed thus far by the Securities and Exchange Commission permit, in addition, the writing off of such costs to capital surplus. All the new systems require the extinguishment of any applicable remaining financing costs in these two accounts upon reacquisition or (except in the Securities and Exchange Commission systems) retirement of stock.

(4) Segregation of Transactions between Affiliated Interests. Provision is made for full disclosure of transactions between affiliated interests. All charges by affiliated companies must go through a mandatory

22. The New York system of accounts provides only for "Capital Stock Expense", presumably because under New York statutes (N. Y. Stock Corporation Law \$ 69) stock of public utility corporations may not be issued for less than par.

23. The new systems of accounts for New York differ only in that they do not provide a separate balance sheet account for discount on capital stock, although an account for capital stock expense is provided. However, a note to Account 301, Organization, specifically excludes "any discounts upon securities issued or assumed." 
clearing account before being spread in other accounts. "The records supporting this account shall be so kept as to show the nature of each charge together with the account or accounts to which each charge is cleared." 24 This is designed to bring together in one place all such charges, so that they may be readily analyzed and traced to the primary accounts in which they are finally recorded.

Four special accounts are provided in the balance sheet for recording such transactions. Among the assets are account 111, Investments in Associated Companies, and account 126, Receivables from Associated Companies. Among the liability accounts are account 212, Advances from Associated Companies, and account 223, Payables to Associated Companies. In the operating expense accounts is account 794, Management and Supervision Fees and Expenses.

(5) Depreciation Accounting. In the older systems of accounts for electric utilities, the provisions relating to depreciation were very general and loose. An account was provided in the income statement for recording "Retirement Expense", and a "Retirement Reserve" account vas included among the liabilities. The classifications expressly or tacitly permitted the practice of making provision for retirements contingent upon earnings available for dividends. Most electric utilities, therefore, adjusted retirement expense according to financial expediency and the desire or need for dividend distributions.

The new accounting systems embody significantly different principles. In the new accounts, depreciation is treated as a cost which is to be reflected in the income statement for each accounting period.24s Instead of depending in a large measure upon the whims of the financial managers, it is defined as "the loss in service value not restored by current maintenance incurred in connection with the consumption or prospective retirement of utility plant in the course of service from causes which are known to be in current operation and against which the utility is not protected by insurance. Among the causes to be given consideration are wear and tear, decay, action of the elements, inadequacy, obsolescence, changes in the art, changes in demand and requirements of public authorities." ${ }^{25}$ Thus defined, depreciation is an element of cost regardless of

24. National Assoctation of Ralload and Utmetties Cosorissloners, Unifozur System of Accounts for Electric Utrutries, Account 90, Charges by Associated Companies-Clearing, par. C.

24a. However, depreciation on properties held for future use, in the new accounting systems, is not to be charged to operating expenses.

25. National Association of Ratiroad and Utiltries Coanarissioners, Umifozis Systear of Accounts for Electric Utilities, Definition 13. Cf. Secursties and Exchange Coumission, Uniforar Systeas of Accounis for Public Utulty Holdng Cospantes, Account 229, Depreciation, and Account 180, Reserve for Depreciation. In the latter system, "it is the purpose of the reserve to accumulate during the useful 
the financial fortunes of the business. Items of plant and equipment inevitably march toward the scrap-heap whether or not earnings are available for interest or dividends. Failure to record depreciation understates the cost of rendering service during an accounting period and tends to mislead investors and others. In this respect the new systems of accounts follow in the main the views of the Interstate Commerce Commission ${ }^{26}$ and are a radical departure from most of the previous classifications for electric utilities.

The new classifications do differ among themselves in one respect the method of accruing depreciation. Some are explicit; others are general so as to permit use of different bases of accrual. In this, they reflect the sharp conflicts of opinion existing on this subject. The federal system of accounts for telephone companies and the New York system for electric corporations are explicit in prescribing straight-line depreciation accounting. ${ }^{27}$ The National Association's classification for electric utilities requires no particular method of accrual, in deference to the varied opinions of state commissions. The Federal Power Commission system of accounts does not expressly require straight-line depreciation accounting, but the utility is required to classify both annual depreciation expense and the depreciation reserve by six functional groups of property-steam production, hydro production, internal combustion engine production, transmission. distribution, and general. ${ }^{28}$

(6) Uniformity of State and Federal Classifications. The possibility of jurisdictional disputes between federal and state regulatory authorities was enhanced with the enactment of the Federal Communications Act, ${ }^{20}$ Federal Power Act, ${ }^{30}$ Motor Carrier Act, ${ }^{31}$ and Public Utility Holding Company Act. ${ }^{32}$ The states, mindful of what happened to their powers

life of physical property an amount sufficient to write off the book cost, plus cost of removal, less salvage, of all classes of depreciable property included in Account 101, Miscellaneous Investments. Credits to this account shall be made in such way that operations of each year shall bear a proportionate share of the burden. Debits shall be made in such way as to accomplish the purpose stated ..."

26. Telephone and Railroad Depreciation Charges, 177 I. C. C. 351 (1931).

27. Federai Communications Commission, Uniform System of Accounts roz Telephose Conpanies, Instructions 80-83, incl.: New York Public Service ComMission, UNiform System of Accounts for Electric Corporations, Instruction 8.

28. Under these provisions direct controversy, with either utilities or state commissions, is avoided until the Federal Power Conmission prescribes a particular method of accruing depreciation. Conflict is then likely to ensue when state requirements differ and the utility is under both jurisdictions.

29. Federal Comaivications ACt of 1934, 48 Stat. 1064, 1102, 15 U. S. C. §21, 47 U. S. C. $\S \S 35,151-609$ (1934).

30. Federal Power Act, 49 Stat. 838, 16 U. S. C. A. §791a (Supp. 1935).

31. Mlotor Carrier ACt, 1935, 49 Stat. 543, 49 U. S. C. \$§301-327 (Supp. 1935).

32. Public Utility Holning Company ACt, 49 Stat. 838, 15 U.S.C.A. $\$ 79$ (Supp. 1935). 
over intrastate business in the field of railroad regulation under the Shreveport doctrine, ${ }^{33}$ were inclined to be suspicious of the expansion of federal regulatory power, and sought to protect their powers as they could. There is, of course, little justification for jurisdictional conflicts in matters of account classification. Many utilities are under the jurisdiction of two regulatory bodies. To meet inconsistent accounting requirements by the two administrative agencies would entail additional expense for accounting which in the long run would probably have to be borne by the ratepayers. In view of the possibility of conflict, it is therefore an achievement of considerable public importance that such a high degree of uniformity has been secured under the new accounting systems. It is still too early to determine how many states will actually adopt the federal classification of accounts for telephone companies, or either the federal or National Association's classifications for electric utilities. But it is significant that the National Association has endorsed the federal system of accounts for telephone companies and has recommended a systim for electric utilities which is practically identical with that of the Federal Power Commission. Indeed the latter has recently amended its system of accounts to bring it more in line with that of the Association, ${ }^{34}$ and the Communications Commission has likewise made last-minute amendments, ${ }^{35}$ following the decision in the American Telephonte and Telegraph Co. case, which were previously submitted to the National Association's Committee on Accounts. While it is to be expected that some state commissions will find it necessary to make additions or revisions in order to meet requirements of state statutes, ${ }^{30}$ the main structure of the accounting systems for telephone and electric utilities seems destined to be substantially uniform under both federal and state regulation.

The possibility of conflicts between the two jurisdictions does not end when a new system of accounts is ordered. Any system of accounts requires interpretation from time to time. Inconsistent interpretations by state and federal accounting authorities will in the course of time destroy uniformity in applying the system of accounts. Such a result can be avoided if both state and federal agencies arrange for consultation or exchange of views on such interpretations. This kind of cooperation between agencies whose authority is in part exclusive, in part concurrent, is no novelty in a political system operated according to rules of dual sovereignty, and is becoming an increasingly important issue in administrative law and practice.

33. Houston \& T. Ry. v. United States, 234 U.S. 342 (1914).

34. Federal Power Commission, Order No. 43, Dee. 31, 1936.

35. Federal Communications Commission, Telephone Division, Order No. 7-D, Jan. 6, 1937.

36. For example, see the classification of accounts prescribed December 21, 1936, by the Public Utilities Commissioner of Oregon. 
3.

These and other features of the accounting systems were warmly and thoroughly debated before resort was had to the courts to test their validity. To give a full-length picture of the uniform accounting movement, it is important to review this discussion briefly, primarily from the standpoint of regulatory policy.

Attacks have been centered chiefly on the original cost principle. It has been dubbed the "principle of aboriginal cost," ${ }^{37}$ and condemned as unsound for a variety of reasons. (1) It is said that original cost accounting requires from $80 \%$ to $90 \%$ of the total assets of a utility to be "deliberately misstated" by recording property at estimated figures which are neither cost nor value, do not represent cost to the accounting company and in fact destroy the ability of a company, after a few years, to ascertain exactly what the assets cost the company, and which necessitate write-ups and write-downs of asset values. (2) The movement scraps the accounting principles laid down by commissions and followed by utilities for 25 years. (3) The new system designates part of the property by a term ("Acquisition Adjustments") "which of itself seems to cast doubt upon its legitimacy" and therefore frightens investors and injures the company's credit. (4) A meaningless and costly reclassification of present property and plant is required. (5) Utilities are required to estimate retirement reserves that should have been accumulated by predecessors had they followed a certain concept of depreciation accounting, to increase such reserves accordingly, and to record in the Adjustment Account deficits in past accrued depreciation with which the present owners had nothing to do. (6) A commission may direct that part of the fixed assets be written off against surplus, which results in confiscation. (7) A great and unnecessary increase in accounting expense is thrust on the utilities, to the detriment of ratepayers and investors, when less costly and more satisfactory means of providing relevant information are available. ${ }^{38}$

The attack does not stop there. The proponents of the original cost principle are accused of fantastic fallacies. In answer to the assertion that the new system furnishes important information in aid of regulation or investment, it is said that: (1) the accounting definition of original cost differs from that used by the Supreme Court; (2) the Supreme

37. Chamberlain, Regulation by Accounting-An Inuovation (1935) 3 Edron Electric Institute Bulletin 301; Gruehn, Aboriginal Cost (1936) 4 Edison Electric INSTITUTE BUt.LETIN 272.

38. Mr. Chamberlain also criticized the frequency of requiring resort to a commission for authority to make, or for approval of, particular accounting entries. This criticism was apparently based on an earlier draft of the accounting classification which was materially modified in this respect in the final draft. Chamberlain, supra note 37, at 302 . 
Court has never said that original cost could be used as the only or the major factor evidencing value; (3) the Supreme Court has never sustained the theory of depreciation described in the accounting classification nor required a present owner of property to record "hypothetical deficits in past accrued depreciation"; (4) cost to the accounting company cannot be maintained under the proposed classification and this is the important fact to security holders and to management. The utilities did not exhaust their arsenal of adjectives when they described the original cost principle as arbitrary, misleading, impractical, unconstitutional, fanciful, costly, and a gross abuse of power.

On the other side of the controversy, the advocates of original cost and the associated reclassification of property required by these accounting systems cite illustrations of the usefulness of such information for speedy and effective regulation, particularly in rate-making. Original cost accounting, it is said, will make constantly available one of the two ruling criteria of valuation for rate making. The provision of information required by the new accounting systems serves another end as well: giving more exact information to the investment public. Informed investors may wish to know how much more than original cost of installation was paid for property by the present owners, how much intangible value is attached to the value of physical property, or how much of the property is held for future use or leased to others. They .are balked in seeking such information from the present accounting statements of many utilities. In such cases, few know, sometimes not even the company officials, what level of valuation was used in stating fixed assets or what items compose the totals shown. In most cases such information is unavailable to investors at large; and institutional investors, or regulatory commissions, can get it only after tedious and expensive audits or appraisals of the property. ${ }^{39}$

Regulatory commissions make varied uses of the ledger values of utility property. Such data are useful not only in rate proceedings, but also in passing upon security issues, in reviewing depreciation rates, in checking rate schedules negotiated with utilities or proposed for filing, and in reviewing the valuations underlying tax-assessments. These jobs

39. If illustrations are needed, a few from one state can be presented. One company was acquired by the present interests 20 years ago. After two decades, with one change in accounting classification at the end of the first decade, only $14 \%$ of the reported fixed capital was properly classified by primary plant accounts. Nearly half was classified into five broad groups of property and nearly $40 \%$ was not classified in any manner. Four of the larger utilities reported over one-fourth of the electric fixed capital as either "cost of plant and equipment purchased," or "not classified by preseribad accounts." Of the reported fixed capital of all the Class A electric and joint utilities, over $16 \%$ was shown in the above two unclassified groups or as not classified by utility service. 
cannot be done quickly if original cost figures are not readily ascertainable from the face of the utility's accounts but instead must be dug out by laborious, expensive, and time-consuming audits or property appraisals. ${ }^{40}$ As a practical matter, the case for original cost as the basis of plant accounting may be outlined as follows: (1) Original cost, as defined in the system of accounts, is concededly relevant in valuation proceedings, and hence should be constantly available in complete and easily administrative form. (2) Original cost, being relatively stable, promotes uniformity in plant records and statistical data. (3) Original cost affords a more useful basis of accurate accounting for plant retirements. (4) Determination of original cost in most instances requires no more difficult estimates than are needed in complying with other provisions of this or other systems of accounts. (5) Once original cost of acquired property is established, accounting expenses are no greater than those required by other methods of recording property, if adequate plant records are maintained. (6) The original cost basis of accounting is worked out in the new system of accounts so as not to destroy the record of cost to the accounting company. (7) Adequate provision is made for permitting the depreciation or amortization of any legitimate amount in excess of original cost that is paid by the accounting company for purchased properties. At least since Smyth v. Ames, ${ }^{41}$ the Supreme Court has repeatedly acknowledged the propriety of using original cost figures in valuation for rate making purposes, although it is of course by no means clear what weights the court requires to be attached to original cost as a factor in valuation, or whether those weights vary with economic circumstances. Even the court's most pronounced experiments in reproduction cost valuation, however, recognized the relevance of original cost to the process of fact finding and administrative judgment implicit in valuation. Thus one clear purpose which the new accounting systems will serve is quickly to supply the Commissions and the courts with one of the statistics they require in valuation. Almost without exception, ${ }^{42}$ moreover, the courts have used original cost in essentially the same sense as the accounting definition..$^{43}$ Commissions have considered

40. For more extended exposition of this situation, see Brief for the United Stateg, pp. 22-23, 25, 34-38; Brief for Federal Communications Commission, p. 38; Brief on behaif of the National Association of Railroad and Utilities Commissioners, pp. 22-30 in American Tel. \& Tel. Co. v. United States, 57 Sup. Ct. 170 (1936).

41. 169 U.S. 466 (1898).

42. In Los Angeles Gas \& Elec. Corp. v. California R. R. Comm., 289 U. S. 287 (1933), reference is made to the "actual cost of the property-the investment the owners have made-" as a "relevant fact."

43. Cost of construction is the factor referred to in Missouri $c x$ rel. Southwestern Bell Telephone Co. v. Pub. Service Comm. of Missouri, 262 U.S. 276 (1923); 'and in St. Louis \& O'Fallon Ry. v. United States, 279 U. S. 461 (1929). See also 1 WnITten, Valuation of Public Service Corporations (2d ed. 1928) c. 14. There appcars 
original cost as a factor not only in determining a fair rate-base but also in passing upon security issues, depreciation rates, and rate scliedules proposed for filing." They have found such data helpful in judging the reasonableness of present value estimates as well as in detecting "write-ups" and intangibles included in property accounts. ${ }^{\text {"s }}$

The use of original cost will promote greater uniformity in plant records than now exists. Many utilities today have their property recorded partly at original cost, and partly at reproduction cost new, at reproduction cost new less depreciation, at cost to the company, or at some fiat value established by a promoter interested in selling securities. It has been found that going value, water power value, franchise value, even bond discount, have been included in the plant accounts. Not infrequently, a "cost to the company" is claimed which includes overhead expenses that were never incurred, or, if incurred, were originally charged to operating expenses and recouped from the rate-payers. Under the new systems of plant accounting, all these variations from original cost of tangible property are intended to be placed in one account where they can be more readily analyzed. Once this segregation is accomplished, comparison of the costs of plant to different companies may be made with more assurance. Statistical data which the Federal Power Commission, ${ }^{40}$ and state commissions are required to compile will be made more useful.

Similarly a more stable basis of plant accounting has often been sought in depreciation, and the use of the original cost principle offers one. When property is transferred, the purchaser (if not subject to an original cost accounting system) may set up his depreciation accounts with reference to the purchase price, so that a transfer of ownership may carry with it a sharp change in the depreciation claimed for the property, a fact with

to be a theoretical difference of minor significance between the accounting definition of original cost of property "when first devoted to public service" and the term as used by the courts without this qualification. In a few cases property now used for utility purposes may originally have been installed and used by a private company for its own, non-utility service, e.g., generating equipment installed for use in cosl mines, and subsequently acquired by a utility. In the accounting system, the cost to the compang first using the property for public utility service is intended as original cost.

44. See note 40 , supra.

45. Federal Trade Consasission, Utimtty Corporations, Sew. Doc No. 92(72-A), 70th Cong., 1st Sess. (1928) 845. "The ledger values of the copital assets of all the companies examined, including both holding and operating companies, contained rery large amounts of write-ups. It was found that the combined amount by which the capital assets of all the companies examined were vritten up in value over cost exceeded 1.4 billion dollars. Of this amount, $\$ 273,420,165$ vas in the 18 top holding companies examined, $\$ 309,495,058$ was in the 42 subholding companies examined, and $\$ 599,327,206$ was in the 91 operating companies examined. Additional amounts of $\$ 43,874,977$ and $\$ 264,904,417$, respectively, were found in other subholding and oparating companies principally in connection with the examination of their holding companies."

46. Federal Power ACT, 49 Stat. 838, 16 U. S. C. A. \$825-c (Supp. 1935). 
puzzling consequences both for the company and for the Commission charged with regulating it. If depreciation expense is based on original cost, any additional allowance for depreciation or amortization that may be justified in recognition of the resale at a higher price can be allowed with clear recognition of what the allowance is supposed to cover. When an operating unit or system is purchased, it ordinarily is soon merged with property installed by the utility and the identity of the purchased property is lost. Upon retirement from service, the amount written out of the plant accounts may be greater or less than the purchase price. If the retirement value is greater than cost to the company, the remaining property is understated; if less, a residue of book value remains in the accounts which should not be there, for the property is gone. Although the refinements of depreciation accounting on the unit basis are not required, the use of original cost should facilitate a more accurate estimate of retirement values and thus lessen the opportunities for unrecorded retirements or over-retirements.

Critics of the new accounting classifications have asserted that for property now in use original cost is generally obtainable by estimate and that such estimates are bound to be inaccurate, especially where the predecessor company or companies kept no records or inadequate records, or the records have been lost.7 Unquestionably estimates of original cost must be made where facts are not available. But valuation proceedings are full of estimates. Cost of reproduction, after all, is a highly theoretical kind of estimate. ${ }^{48}$ It has not been shown that estimates of original cost are more uncertain or inaccurate or impossible than other kinds of estimates commonly used in valuation proceedings or in utility accounting. ${ }^{40}$

Allegations that the new methods of plant accounting are more costly than the old ones, are difficult either to prove or disprove ${ }^{50}$ because experience has been so limited. In Wisconsin where several determinations of original cost have been made, the expense involved has not exceeded that of making an inventory and appraisal. This cost should be nonrecurring, if reasonably accurate accounting methods are pursued in the future. Advocates of the system point out that the initial expense of determining original cost of the acquired property should not be confused with the expense of keeping it up to date. Assertions have been made that the new basis of accounting, once established, has made possible

47. Brief for Plaintiffs, 48, in American Tel. \& Tel. Co. v. United States, 14 F. Supp. 121 (S.D.N.Y. 1936).

48. Cf. Ohio Utilities Co. v. Public Util. Comm. of Ohio, 267 U.S. 359 (1925).

49. See the oral argument of Hon. John E. Benton before the United States Supreme Court in American Tel. \& Tel. Co. v. United States, 57 Sup. Ct. 170 (1936).

50. Brief for the United States, p. 54, in American Tel. \& Tel. Co. v. United States, 57 Sup. Ct. 170 (1936). 
certain savings in the expense of plant accounting. At present this virtue can be claimed only as a possibility, or at best a probability, depending upon the detailed routines established for continuing the record. But even if this method of plant accounting were more costly to keep current than less elaborate accounting systems, any greater expense should be balanced against the greater usefulness of the information so obtained and the alternative cost of periodic appraisals of original cost as occasion arises. Finally, it should be mentioned that part of the allegedly greater cost of using an original cost accounting system arises from the necessity of unscrambling the "undistributed cost of property" which so many utilities report ${ }^{51}$ and which, as a major vice of their present plant accounts, the proposed systems are intended to correct.

Whether or not the original cost basis of plant accounting destroys the record of cost to the accounting company has been warmly debated among the professional accountants. ${ }^{62}$ Two points have emerged from their discussion. (1) Present practices of recording merged or acquired properties are so varied that it is questionable whether cost to the accounting company is preserved even under existing systems of accounts. Some companies record acquired properties at the predecessor company cost and take over the accrued depreciation or retirement reserve; others enter the property in the accounts at appraised cost of reproduction new and add to the reserve the accrued depreciation determined by. the appraiser; still others record in the plant account cost of reproduction less depreciation and do not record accrued depreciation in the reserve; and still others enter the purchase price, however determined, in the plant account with no change in the depreciation reserve. (2) Whatever method of recording acquired properties is used, as soon as retirements of such property are made, the cost of acquisition to the purchasing company is impaired under the retirement accounting practices of most utilities. In any event the mechanics of the new system of accounts are such as to permit recording both original cost and cost to the accounting company at the time of acquisition.

Other aspects of the proposed systems which have caused dissension among the accountants are the treatment of stock discount and selling expense, and the provisions for depreciation accounting. The accounting treatment of capital stock discount and selling expense is challenged largely because it is an assault upon that convenient catch-all, "organization expense," thereby curtailing the amounts which may be included in the property accounts. It has been assailed as a wrongful taking of property because these items have always been considered as part of organization expense; because they are necessary costs of organizing and

51. See note 39 supra.

52. See e.g., articles by Chamberlain and Gruehn, both supro note 37. 
carrying on a business; and because they are not subject to amortization over any particular period, since stock has no pre-determined maturity date.

On the other hand, the Federal Trade Commission's report ${ }^{63}$ lists numerous instances where surreptitious profits were given to insiders in transfers of stock ownership and carried into the property accounts by manipulation of stock discounts and selling expenses. The new accounting treatment is designed primarily to bring such transactions into the open. The argument is also made that stock discount and selling expense are merely costs of equity financing similar to bond discount and expense. The absence of a maturity date is no obstacle to amortization, if desirable, over a reasonable period..$^{54}$

Reactions to the depreciation accounting requirements in the new systems of accounts have varied. The telephone industry, having long followed straight-line depreciation under prevailing court decisions, ${ }^{\mathrm{bC}}$ raised no objection to this requirement with respect to property in service. The electric utilities raised serious objection. In the other classifications, no particular depreciation policy was expressly prescribed. Indeed, to meet the varying views of state commissions, the text of the National Association's classification is so general as to permit almost any method of depreciation accounting. ${ }^{58}$ The Federal Power Commission's classification is similarly general but in requiring a breakdown of depreciation charges and reserves by groups of primary plant accounts, a struggle portends

53. Federal Trade Comaission, Utility Corporations, Sen. Doc. No. 92 (72-A), 70th Cong., 1st Sess. (1928).

54. One phase of this question has been neglected. If stock discount and expense are amortized, are the annual provisions for amortization deductible for income tax purposes? It would appear not, unless the rulings of the Internal Revenue Bureau are changed. U. S. Treas. Reg. 94 , art. 22 (a) -16 .

55. It has been customary practice for most telephone companies, especially those in the Bell system, to accrue depreciation reserves on the straight-line basis, but in valuation cases they claim that accrued depreciation determined on different bases is much less than that for which they have made provision by charges to operating expenses. Cf. Chesapeake \& Potomac Tel. Co. v. Whitman, 3 F. (2d) 938 (D. Md. 1925); New York Telephone Co. v. Prendergast, 36 F. (2d) 54, 65-66 (S. D. N. Y. 1929); $R e$ Wisconsin Telephone Co., 13 P. U.R. (N.S.) 224, 301-302 (1936); Puburc SErvice Commission of Wisconsin, Deprectation: A Review of Legal and Accounting PropLEMS (1933).

56. "Account 503, Depreciation. This account shall include the depreciation expense applicable to utility plant in service (account 100-1) for the period covered by the income account, except such depreciation expense as may be charged to clearing accounts or to construction work in progress."

See also General Instruction 9: "Each utility shall record as of the end of each month the estimated amount of depreciation accrued during that month on depreciable utility plant. (See account 503, Depreciation, and account 250, Reserve for Depreciation of Utility Plant.)" 
with those utilities who wish to continue making retirement provisions dependent upon earnings.

Other provisions of the new systems of accounts than those herein discussed have been criticized by utility officials and accountants. ${ }^{57}$ However, this is not the proper occasion for a review of the accounting details. In this article, the controversy as to accounting and administrative procedure serves mainly as background for an analysis of the two principal legal assaults upon the new accounting systems.

4.

Failing in the attempt to persuade commissions not to adopt the new principles, the utilities resorted to the courts. The case for the utilities was based on the argument that to force them to show on their books the "original cost" of their property, if different from cost to the accounting company, to amortize ledger values other than original cost separately from depreciation, or to require deductions from surplus was confiscatory taking of the utilities' property, in violation of the Fifth or the Fourteenth Amendments. A compulsory accounting system was a taking of property, they contended, because corporate books are the source of data crucial in public regulation, financing, and in influencing the judgment of investors, so that prescribed rules of accounting would affect the companies' income and capital value. Two actions were commenced, one in New York, the other in the federal courts. In the former action, the utilities were successful; in the other, they largely failed. However, these two cases, when tied to three prior Supreme Court decisions upholding the Interstate Commerce Commission's power to prescribe uniform accounting and to require statistical information, ${ }^{83}$ do throw some light upon the probability of holding the revised systems of accounts valid.

The first case dates from 1912. The Goodrich Transit Company engaged in both interstate and intrastate water transportation; part of its business was joint rail and water interstate transportation. Eighty per cent of its business was alleged to be intrastate. Likewise, the White Star Line claimed that only $1 \%$ of its revenue was derived from interstate joint rail-water traffic; in addition it operated two amusement parks.

57. See "Comments, Suggestions, and Recommendations", "Mfemorandum re Depreciation Charges and Reserves and the Recording of 'Original Cost' of Property.", submitted by the Accounting Committee of the Edison Electric Institute, March, 1936, and April 10,1936, respectively, to the Committee on Statistics and Accounts of Public Utility Companies of the National Association of Railrosd and Utilities Commissioners and to the Federal Power Commission.

58. Interstate Commerce Commission v. Goodrich Transit Co., 224 U. S. 194 (1912) ; Kansas City Southern Ry. v. United States, 231 U.S. 423 (1913); Norfolls and Western Ry. v. United States, 287 U. S. 134 (1932). 
These two carriers cliallenged the Interstate Commerce Commission's requirements that revenues and expenses of interstate, intrastate, and non-transportation business be reported separately and objected to furnishing information regarding intrastate and non-transportation business. The lower court held that the Commission had power only to prescribe uniform accounting for interstate business. ${ }^{59}$

On appeal, the Supreme Court reversed the lower court's judgment. ${ }^{80}$ In sweeping aside the familiar argument that the Commission's authority to prescribe uniform accounting was an unconstitutional delegation of legislative power, the Court used language that is pertinent today.

"If the Commission is to successfully perform its duties in respect to reasonable rates, undue discriminations and favoritism, it must be informed as to the business of the carriers by a system of accounting which will not permit the possible concealment of forbidden practices in accounts which it is not permitted to see and concerning which it can require no information . . . Further, the requiring of information concerning a business is not regulation of that business." 61

A year later the Supreme Court again upheld the Commission's accounting regulations in a more difficult set of circumstances. ${ }^{02}$ The carrier was reconstructing its line in order to take care of increased traffic. The rehabilitation was accomplished largely by reducing grades on existing right of way and partly by.building short sections of new line in substitution of existing right of way. Six sections of new road were built at a cost of nearly $\$ 764,000$, and use of the displaced roadbed was discontinued. The improvement was to be financed by a bond issue, and a portion of the bonds, in the amount of $\$ 1,250,000$ has been sold. To facilitate the sale of bonds, the carrier began payment of non-cumulative dividends on preferred stock at the rate of $4 \%$.

Accounting regulations of the Interstate Commerce Commission required that where a property betterment was on new roadbed, only the excess cost of the betterment above the replacement cost of portions of track and right of way no longer used was to be added to the property accounts. The abandoned track and roadbed, as well as an abandoned shop and terminal plant, were to be charged off to operating expenses.

The carrier complained that it should not be required to write off the abandoned property in the manner prescribed. To do so would increase operating expenses so that preferred dividends could not be declared, which in turn would injure the carrier's credit, prevent sale of the bonds,

59. 190 Fed. 943, 966 (Comm. Ct. 1911).

60. Interstate Commerce Commission v. Goodrich Transit Co., 224 U. S. 194 (1912).

61. Id. at 221 .

62. Kansas City Southern Ry. v. United States, 231 U. S. 423 (1913). 
and stop the entire improvement. The regulations were alleged not only to deprive preferred stockholders of dividends but also to require the carrier to return money already borrowed from bondholders. The only way for the carrier to avoid these results, it was asserted, was to adopt a more expensive plan of betterments by reducing grades only on existing right of way.

Nevertheless, the Commission's regulations were upheld, the Court placing its decision on a ground of considerable significance:

"The present attack upon the classification as adopted is, and must be, rested at bottom upon the contention that the regulations embodied in it are so entirely at odds with fundamental principles of correct accounting as intrinsically to manifest an abuse of power." ${ }_{3}$

It further recognized the long-standing and unchallenged distinction between operating and capital expenses and the need for this distinction in fixing rates. The carrier's contention, in the Court's opinion, "in effect ignores depreciation-an inevitable fact which no system of accounts can properly ignore. A more complete depreciation than that which is represented by a part of the original plant that through destruction or obsolescence has actually perished as useful property, it would be difficult to imagine." ${ }^{\text {S4 }}$ After reviewing the treatment of depreciation in the accounting regulations, the Court expressed the opinion that "the regulation is not arbitrary in the sense of being without reasonable basis. And there is evidence to show that the Commission was warranted in adopting it, as sustained by expert opinion and approved by experience." (Italics supplied) ${ }^{\text {es }}$

63. Id. at 444 .

64. Id. at 448 .

65. Id. at 452: The Court also considered the question whether there was an mlawful taking of property, if the regulations resulted in depriving preferred stoclholders of dividends. The Court thought not. Accounting requirements cannot be aroided by agreements among stockholders apportioning earnings. To admit this vould "tend to render impracticable the standardization of methods of accounting." (454). The Court similarly brushed aside the argument that the regulations required the carrier to return money already borrowed from bondholders. If the loss is charged so operating expenses and income available for dividends disappears and yet dividends are continued, they would appear to be paid out of proceeds of the bond issue. "Since one of the very purposes of establishing the accounting system is to deter the payment of dividends out of capital, the criticism, upon analysis, bears its ovm refutation" (455).

Also significant, as showing the scope of the discretion allowed the Commission, is this sentence. "But, did we agree with appellant that the abandonments ought to be charged to surplus or to profit and loss, rather than to operating expenses, we still would not deem this a sufficient ground to declare that the Commission had abused its power." (456) 
Not until 1932 did the Court have occasion again to review ${ }^{66}$ a clearcut dispute over accounting regulations. The Norfolk \& Western Railway Company, having experienced difficulty in obtaining an adequate supply of locomotive fuel in the period from 1917 to 1920, bought three coal mines, adjacent to its right of way. By the terms of purchase, these mines were to be used "solely for the supply of locomotive fuel." These collieries furnished about $48 \%$ of the carrier's locomotive fuel requirements. The investment, after deducting depreciation and depletion, was $\$ 2,650,467$. The Interstate Commerce Conmission instructed the carrier to record these mining investments in its accounts as nontransportation property, to account for revenues and expenses therefrom as miscellaneous operations, and to clarge into railway operating expenses the average montlly production cost per ton of coal produced in the collieries for use in transportation operations. The carrier claimed these mines were properly classifiable as transportation property.

Again the Commission was sustained. The Commission's accounting instruction was not in exress of its statutory power, for the Commission, to perform its dutics under the act, must draw a line between transportation and nun-transportation property. With commendable selfrestraint. the court remarked:

"The record shows that it is unusual for a raihroad to own mines for the production of lomotive fuel: in fact we are referred to no other sinilar instance. Whether the Commission should make special classifications to fit exceptional cases lies within the discretion conferred. and courts ouglit not to be called upon to interfere with or correct alleged errors with respect to accounting practice. If a'c acerc in disagrecment with thic Commission as to the wisdom and propriety of the order, are are without power to usurp its discretion and sul'stitute our oa'n." (Italics supplied)

The Court found no denial of due process of law. The carrier alleged that by the Commission's mandate an unfair and improper rate-base was fixed and capital asset properly to be taken into account in a recapture case was eliminated. To which the Court replied:

"But this is to ignore the fact that the order is one touching accounting merely; that before any" rate base can be ascertained or any basis of recapture determined the carrier will be entitled to a full hearing as to what property shall be included; and not until the Commission excludes the assets in question from the calculation may the carrier assert the infliction of injury to its rights of property. . There is no right to a particular form of accounting as such." (Italics supplied) $)^{\text {ot }}$

66. Norfolk and Western Railway Co. r. Lnited States. 2S; L'. S 134 (1932).

67. Id. at 141. 143 . 
In New York Edison Co. v. Maltbie, ${ }^{\text {es }}$ electric, gas, steam or water utilities challenged the validity of revised systems of accounts applicable to their respective services. Of the five provisions assailed, only one was held valid. It is necessary to examine the opinion of the Appellate Division to find the grounds for this holding; the Court of Appeals merely affirmed the lower court, per curiam, stating that the orders of the Public Service Commission as construed by the Appellate Division "directly interfere with private property rights," and for that reason could be annulled on certiorari.

The Appellate Division opinion is a strange, vague mixture of statutory interpretation and constitutional doctrine. Thus, the requirement of a perpetual inventory was upheld on the ground that specific authority had been granted by the legislature. ${ }^{09}$ But the straight-line depreciation requirement was held ultra vires the Commission because "the Legislature has not granted (it) power to fix the method of setting up depreciation reserves." However, the Court went further; it indicated its belief that any attempt at such regulation would be invalid because depreciation is "a managerial problem which should not be controlled by the uniform system of bookkeeping established by the Commission." The court also relied on $M c$ Cardle v. Inddianapolis Water $\mathrm{Co}^{70}$ as evidencing the disapproval of the United States Supreme Court of straight line depreciation. But even if the Supreme Court in that case did indicate a preference for the actual observation available in the particular case rather than service life estimates used by the regulatory authority to determine depreciation, its view was there a dictum, applied in any event to the facts of a rate making case, and by no means demonstrates a deep seated constitutional conviction that straight line depreciation is for all purposes illegal. That case can hardly be offered alone as ground for outlawing an integral part of a uniform system of accounts which, since the MicCardle case, has been accepted by accountants and shown to be justified by experience. ${ }^{11}$

Likewise, the requirement that regulatory commission expenses be carried to a suspense account and not charged to operating expenses until the Commission directed, was held to be "an unwarranted assumption of authority," no such power having been granted by the legislature. But, in addition the Court adds: "If the Legislature had granted such power, a serious question as to its constitutionality would arise, as these expenses should not be paid from a capital account." This

68. 244 App. Div. 685, 281 N. Y. Supp. 223 (3d Dep't 1935), aff'd 271 N. Y. 103, 2 N. E. (2d) 277 (1936).

69. PUB. SERv. Comrsi. Law $\$ 114$, added by L. 1934, c. 287.

70. 272 U.S. 400 (1926).

71. See Public Service Comorission of Wisconsin, Depreciation: A Reytew of Legal and Accounting Problezss (1933) 97 et seq. 
statement is of course obiter; and a misconstruction of the accounting requirements as well.

The Appellate Division also held the prescribed accounting for capital stock expense invalid on the ground that since expenses involved in marketing capital stock are "elements of value on which a utility corporation is entitled to receive a return," to prevent the utility from listing it as a property asset is confiscatory. The court cited Ohio Utilities Co. v. Public Utilities Commission ${ }^{72}$ as justifying its conclusion. The latter case does not, however, support this position. There the Supreme Court frowned upon indiscriminate elimination of all organization expenses from a reproduction cost estimate as arbitrary. The decision is by no means binding authority against the validity of a requirement for the segregation of capital stock expense from property accounts.

The major part of the Appellate Division opinion held the New York method of accounting for acquired property on the basis of original $\operatorname{cost}^{73}$ arbitrary and confiscatory. Relying on the Iroquois Gas case, ${ }^{74}$ although the holding there involved a wholly different problem, the Court held the Commission without power to impose such conditions, for:

"... to be required to show a loss on the books when none has been suffered is arbitrary. Many of the fixed capital accounts ordered to be redistributed contain entries reflecting purchases from predecessor utilitics that were approved by the Commission and other entries concerning consolidation and purchases which have been approved by courts, including the Supreme Court of the United States. These entries are not made upon the basis of 'original cost' as the Commission now seeks to define it. Financing has been carried on and transactions made on the basis of these figures as to fixed capital. A requirement that a part now be charged off is confiscatory."75

Since the Appellate Division opinion and its affirmance by the Court of Appeals came before the realistic and sympathetic ${ }^{i 6}$ decision of the Supreme Court of the United States in the American Telephone and

72. 267 U.S. 352 (1925). Cf. note 83 infra.

73. Supra, note 21. It will be recalled that the excess above original cost was to be placed in a suspense account and written off against net income as the Commission might by order prescribe.

74. People ex rel. Iroquois Gas Corp. v. Public Serv. Comm., 264 N. Y. 17, 189 N. E. 764 (1934).

75. New York Edison v. Maltbie. 244 App. Div. 685, 689-690, 281 N. Y. Supp. 223, 228-229 (3d Dep't 1935), aff'd 271 N. Y. 103, 2 N. E. (2d) 277 (1936).

76. See Mr. Justice Cardozo's analysis of the relevance of original cost accounting to the problem of regulating telephone companies, American Tel. and Tel. Co. v. United States, 57 Sup. Ct. 170, 173 (1936). 
Telegraph $\mathrm{Co}^{77}$ case, it is difficult to state definitely the present status of the utility accounting revisions in New York or to predict with any degree of assurance what effect the federal litigation will have on the attitude of the New York courts.

The federal litigation was started when forty-four telephone companies, all except seven being members of the Bell system, sought an injunction before a three judge district court restraining enforcement by the Federal Communications Commission of its order prescribing a revised system of accounts, effective January 1, 1936.78 The companies attacked the order on three principal grounds: (1) The order was unsupported by a report stating conclusions and basic findings. (2) The accounting requirements exceed the Commission's statutory power "and are so contrary to the fundamental principles of correct accounting as to constitute an abuse of that power, in so far as they treat of original cost, contributions, certain classifications of telephone plant and depreciation thereon, and just and reasonable charges." (3) The companies are required to obey standards too vague and indefinite to be intelligible. The first objection was over-ruled on the basis of decided cases, and the companies dropped this point in their appeal. The third was disposed of briefly; after distinguishing the authorities cited by plaintiffs, the court pointed out that in doubtful cases risk was avoidable by asking for a Commission interpretation.

The district court concerned itself chiefly with the question whether the particular accounting requirements assailed constituted a "manifest abuse of power." The companies stressed two arguments against the original cost principle-namely, that it prevented the company from showing its actual investment, and that amounts recorded in the Acquisition Adjustment Account could not be depreciated. After comparing the present and proposed systems of accounts, it found the first exception unwarranted: "The requirement that original cost be set forth in accounting records of the telephone companies serves to complete the picture of value in revealing the property's financial background and showing the relationship of a carrier's monetary return to the original as well as to its own investment. It aids the Commission in its duty to determine, from all the pertinent circumstances and factors, the just and reasonable rates which the carrier may exact from its service. Original cost is a relevant factor. The object of the system of accounts might well be to display the pertinent financial operation and throw light upon its present condition. Original cost as a segregated item on a balance sheet may serve to reveal actualities which may be pertinent in fixing a rate base on the capitalized earning power of a property purchased.

77. American Tel. \& Tel. Co. v. United States, 57 Sup. Ct. 170 (1936).

78. American Tel. \& Tel. Co. v. United States, 14 F. Supp. 121 (S. D. N. Y. 1936). 
In making readily available facts which woukd tend to expose discrepancies in valuation, it cannot be said the system is so arbitrary as to be beyond the Commission's power. Forty-seren state public utility bodies acquiesce in the proposed requirements. This is not evidence of unreasonableness." is As to the second objection, the Court pointed out that this assumed the Commission would act inmproperly in the future in not authorizing amortization in lieu of depreciation. "This cannot be presumed. The order provides for alternatives adaptable to the facts of individual cases. This flexibility distinguishes the systen at bar from that held invalid in Nei' I"ork Edison Co. $\approx$. Maltbie." 80

The district court, however, apparently upheld the companies' objections that no depreciation was allowed on property held for future use, although the language of the court is somewhat ambiguous:

"The exclusion of depreciation on this account as an item to be considered in rate determinations may be supportable but it appears. unjustifiable to bar depreciation on this item altogether. IWhere property is withdrawn from service for any portion of its life, upon its final retirement, the depreciation reserve set up for it would be inadequate. This can be adjusted by charging the depreciation to surplus rather than as a current account. Thus a true reflection of the adjusted value of the property would be obtained, and yet the accounts will so set off the item that it may be excluded from consideration as a current expense for rate purposes." 81

This may be interpreted to mean that depreciation charges on property held for future use may be excluded from operating expense accounts, which was the intent of the classification. But in any event, in the final order. the Communications Commission changed the definition of "time of installation" from "the date at which telephone plant is completed ready for service" to "the date at which telephone plant is placed in telephone service." 8 s This change, considered in connection with the definition of "service life" for depreciation purposes, nay be said to accomplish what the district court seems to have had in mind.

The district court struck out the instruction directing a purchaser of property to record contributions made to a prior owner. This provision was regarded as "swelling the assets and liabilities by a fictitious entry." The accounting instruction was designed to perpetuate the record of the

79. Id. at 126.

80. Id at 127 .

81. Id. at 128 .

82. Federal Communications Commission. Telephone Division, Order No. 7-D, Jan. 6. 1937. With respect to depreciation on property held for future use, the modification follows that of the Pubiic Service Commission of Wisconsin, Rc Uniform System of Arcounts for Class A and Class B Telephone Companies, 2-U-902, Dec. 20, 1935. 
sources of capital to finance the original cost of the property. The Commission's final order in compliance with the decree provided for keeping a memorandum record of such acquired contributions.

The companies also objected to the segregation of capital stock expense on the balance sheet. However, the district court held that this was not arbitrary, in view of differences of opinion among accountants, an attitude which contrasts favorably with that entertained with respect to an identical provision by the New York court. ${ }^{83}$

Upon appeal to the United States Supreme Court, ${ }^{84}$ the companies renewed most of their objections, chiefly to the original cost principle. The court selected four of them for discussion. The companies claimed that the original cost provisions prevented them from recording their actual investment, thus misleading interested persons, largely on the ground that the Acquisition Adjustment Account, representing the difference between original and present cost, "must be written off completely." But such an interpretation of the regulation, the Court declared, was an "imputed meaning," "not the true one." "On the contrary, only such amount will be written off as appears, upon an application for appropriate directions, to be a fictitious or paper increment." This construction, derived from the affidavits and from argument of counsel, was fortified, "to avoid the chance of misunderstanding and to give adequate assurance to the companies as to the practice to be followed,"85 by requestirg the filing of the administrative construction of this provision by the Commission itself which allowed retention in the account of amounts deemed to represent a fair investment. ${ }^{80}$ This declaration was accepted by the Court as "binding upon the Commission in its future dealings with the companies," and as serving to distinguish the case from New York Edison Co. v. Maltbie. In the words of the Court, "the administrative construction now affixed to the contested order devitalizes the objection that the difference between present value and original cost is withdrawn from recognition as a legitimate investment." It also removes the charge of arbitrariness on account of the otherwise uncertain fate of any item. ${ }^{87}$

83. The District Court (14 F. Supp. 121, 129) said: "What we say must not be regarded as an endorsement of the indiscriminate exclusion of these expenses from the rate base. (citing the Ohio case) Nor does it mean that expenses of stock flotations subsequent to organization are always necessarily to be regarded as organization expenses." The New York court, on the other hand, apparently interpreted the Ohio Utilities case as holding that stock discount and expenses vere "things of value" includible in a rate base and hence also in the property accounts. See p. 978 sipra.

84. American Tel. \& Tel. Co. v. United States, 57 Sup. Ct. 170 (1936).

85. Id. at 174.

86. Cf. Provision in Public Service Commission of Wisconsin, Rc Uniform System of Accounts for Class A and Class B Telephone Companies: 2-U-902 (Dec. 20, 1935)

87. American Tel. \& Tel. Co. v. United States, 57 Sup. Ct. 170 (1936). 
Paragraph 2 of the same interpretation answered the companies' second objection that they were prevented from recorering depreciation expense on their actual investment, and required to base depreciation charges on cost to a prior owner. And although the provisions for writing off legitimate amounts in the Acquisition Adjustment Account are called "amortization." the "label is unimportant, whether depreciation or amortization, if the stubstance of allowance is adequately preserved." 88

The companies objected, in the third place, to recording estimates of cost which "mutilated" their accounts and exposed then to the risk of criminal prosecution. But the Court pointed out that invalidation of the accounting order on this ground would invalidate Section 213 (c) of the Federal Communications Act also. ${ }^{89}$ Estimates are necessary in any accounting system. Although more estimates may be required in the new system than in others, this does not make the Commission's action unconstitutional. If the estimate is wrong, no substantial hazard of criminal prosecution exists, as long as the mistake was innocent.

Finally, the companies objected to the original cost provisions because of difficulty in determining the amounts to be written out of the Acquisition Adjustment Account when the property is retired. To the Court, this objection seemed insubstantial because the difficulty was no greater than if only a single account had been used.

Company objections to the general instruction requiring "just and reasonable" charges were shortly disposed of. After reciting that the purpose of the instruction was to "prevent padding of the accounts by charges knowingly and wilfully entered in excess of what is just and reasonable," and that only knowing and wilful actions were subject to penalty, the Court commented, with a suspicion of sarcasm: "There is surely nothing arbitrary in establishing a standard of behaviour so consistent with good morals. On the contrary, the need for such a standard has been made manifest for years as the result of intercorporate relations that are matters of common knowledge." 80

The argument that the classification of plant between that used in service and that held for future use was "so vague as to be arbitrary" received no encouragement from the Court. "Property held in present telephone use comes very near to defining itself." It includes spare plants kept in reserve by "prudent administration." But if doubt arises, the Commission can clarify. ${ }^{01}$

88. Id. at 176 .

89. Id. at 176 .

90. Id. at 177 .

91. Id. at 177. 
If generalization from these cases ${ }^{22}$ is permissible, it would seem that a legislature can give a commission power to prescribe uniform accounting for utilities without fear of judicial interference on constitutional grounds so long as the requirements do not amount to a taking of property, or are not grossly at war with accounting principles and experience. It may further empower a Commission to require separate and uniform accounting of joint business not explicitly subject to its regulation, and may require reports showing the extent and character of such non-utility business. And it is permissible for it to choose among conflicting accounting principles and practices those methods which in its judgment best fit its needs for the performance of statutory duties. A utility has no constitutional right to a particular method of accounting, and no taking of property results from a uniform system of accounts as such. Accounting regulations so enacted are, moreover, administrative in character and no formal hearings or findings are necessary before they are adopted in order to comply with the due process clause. In sum total, at least so far as the Supreme Court of the United States is concerned, a "hands-off" policy has been adopted with respect to accounts regulation. And this rule of tolerance is strengthened-if not enlarged-in the American Telephone and Telegraph Co. case. It is true the Court apparently hesitated over the possibility that the Commission might require a utility to write off legitimate investments in purchased properties at a faster rate than under customary depreciation practices or shift them to an account where the burden would fall on stockholders. These doubts were, however, quickly resolved by the somewhat unusual procedure of requesting an administrative construction without waiting for a specific controversy over application of the rules. ${ }^{03}$ Once fortified in this way, the Court seemed to have no further qualms.

In some quarters the decision may be hailed as a famous "liberal" victory for the effective regulation of utilities; and this view is justified, in that the decision tends to strengthen regulation and administrative discretion. But from the standpoint of accounting principle, the ruling can be interpreted as "conservative." It upholds accounting standards sanctioned by use among competent, independent public accountants. It supports the principle that property accounts should be kept clean and

92. See also United States v. Atlanta B. \& C. R. R., 282 U. S. 522 (1931); Atlant3 B. \& C. R. R. v. United States, 296 U. S. 33 (1935); Chesapeake \& Ohio Ry. v. United States, 5 F. Supp. 7 (E. D. Va. 1933).

93. While the Court served warning that the Commission would be held to its construction, does this stop the Commission from changing its mind in the future? If this should happen, and a specific controversy over the altered interpretation should arise, would the Court still hold the Commission bound by its earlier interpretation? In this event, administrative discretion would be circumscribed. (See 57 Sup. Ct. 170, 174). 
understandable, free from theories of appraising and from the values of intangibles only remotely identifiable with physical property. Accountants in long-established private industries not "affected with a public interest" would not tolerate some of the practices of accounting for property that are found frequently among utilities. The reason, I think, is that in the public utility field the pressure is strong to build up a rate-base, as a foil against regulatory action, by showing large property values, whereas in other industries the pressure of competition usually encourages the writing-down of property.

If public utility managements believe that the property accounting requirements of the new system of accounts are too harsh or too strict, they might well ponder whether or not they themselves are largely responsible for the present development. They were the ones who, seeking constitutional protection against commission regulations, evoked those judicial principles of valuation which have been a nightmare and a handicap to effective regulation and which have helped to swerve many utilities from conservative to inflationary property accounting. For these reasons there was poetic justice in the district court's comment that the new requirements were designed to make "readily available facts which would tend to expose discrepancies in a'aluation" ${ }^{94}$ and as such, were not arbitrary.

The Supreme Court's opinion is expected to gruiet the urge of electric utilities to litigate their new accounting requirements. Probably in the future when some commission has determined original cost and issues instructions for recording and disposing of the excess, or if some commission seeks to go beyond the boundaries approved by the Court, when modifying and adopting the system of accounts within its own jurisdiction, further litigation may cnsue. For the present and immediate future, public utility accounting reform has apparently passed through a period of litigation and enters a period of administrative application and interpretation. On this level will be determined the real usefulness of the new systems of accounts. Whether they successfully meet the needs of commissions and investors can only be answered by the future.

94. American Tel. \& Tel. Co. v. L'nited States, 14 F. Supp. 121, 126 (S. D. N. Y. 1936). 